\title{
Impact of Economic Development on Pesticide Use in South-East Europe
}

\author{
Tatjana Brankov, Bojan Matkovski*, Marija Jeremić, Stanislav Zekić \\ University of Novi Sad, Faculty of Economics in Subotica, Department of Agricultural Economics and Agribusiness, \\ Segedinski put 9-11, Subotica, Serbia
}

Received: 25 May 2020

Accepted: 13 August 2020

\begin{abstract}
Although countries in South-East Europe (SEE) traditionally use less pesticide in agricultural production than more developed countries in Europe, primarily due to the extensive character of their agriculture production, it is important to find the level of pesticide use because their usage can have a significant negative impact on the environment, health and social costs. The main objective of this paper is to find the correlation between pesticide use and economic development in SEE countries. In that context, the model for determining economic factors that can influence pesticide use is constructed and estimated. The results show that gross domestic product and precipitation had a positive impact on pesticide use, while farm size, trade openness, and membership in the European Union (EU) had a negative impact. This paper makes a significant contribution to the literature of pesticide use in SEE countries and answers questions which are significant for determining economic factors. This is important for policymakers, especially in countries that are candidates for EU membership, countries that should adopt EU legislation of pesticide use and establish new agri-ecological measures.
\end{abstract}

Keywords: pesticide use, SEE, EU, economic development, environment

\section{Introduction}

After the Green Revolution, an increase in pesticide use in the world has been present, which is related to many environmental and health consequences [1]. Namely, about three billion kilograms of pesticides are applied each year around the world, and the most benefits of pesticides are based on direct crop returns [2]. The pesticides provide economic benefits to agricultural producers and, by extension, to consumers, and one of the major benefits of pesticide use is the protection of crop quality and yield [3]. Also, there are

*e-mail: bojan.matkovski@ef.uns.ac.rs a number of other primary and secondary benefits of conventional pesticide use. The primary benefits are the consequence of direct effects of pesticide use, such as protection of people, animal and crop health, and protection of recreational turf. The secondary benefits are inducted from primary, so they include long term consequences of pesticide use [4]. The benefits include improved crop/livestock yield and quality, improved shelf life of produce, reduction in agricultural labour, energy expenses and soil disturbance, as well as many indirect gains such as improved food safety and security, improved quality of life, reduced migration to cities and reduced stress [5].

However, excessive pesticide use is associated with a very high environmental, health, and social costs. 
Pesticide can affect animal and plant biodiversity, air, soil, surface, groundwater, and non-target species [6]. Pesticide exposure is linked with a birth defect, allergies, asthma, cancer, hormone disruption, etc. [7], and intoxications during its improper applications [8]. Additionally, there are indirect costs of pesticide uses, such as monitoring and sanitation costs for a contaminated ecosystem, absorbed by society [9]. Thus, the ecological and economic sustainability of agriculture needs to pay special attention to increasing environmental costs required to achieve a hypothetically increasing productivity [10].

Considering concerns related to plant protection products, the Seventh Environment Action Programme ( $7^{\text {th }}$ EAP) sets the objective. This objective highlights that by 2020 the use of pesticides should be done on a sustainable way, without any harmful effects on human health or environment [11]. Despite long debates about pesticide use, the total pesticide sales in the European Union (EU) did not decrease. Namely, total pesticide sale remains relatively constant over the period 2011-2016 [12]. However, there are huge differences in country's level of pesticide sales among EU countries. In more than half of the EU members, the average quantity of pesticides sold increased, especially in Bulgaria, Estonia, and Finland [13].Considering regions of the European continent, it seems that the use of pesticides increases in Eastern and Southern Europe and decreases in Western Europe [14]. The differences among countries could be caused by differences in implementing a policy aimed at improving environmental conditions.

Over the past two decades, EU pesticide legislation has been subject to radical change. Quite differently from previous fragmented legislation developed at the national level, the newly adopted legislation provides harmonized approach for all EU member states. The main elements of the adopted pesticide package consist of: Framework Directive to achieve the sustainable use of pesticides, Directive on machinery, Directive establishing a framework for Community action to achieve the sustainable use of pesticides, and Regulation concerning statistics on pesticides [15]. As a response to increasing awareness about the hazards and risks to health and the environment posed by the use of pesticides, current EU legislation emphasizes their sustainable use and adoption of integrated pest management (IPM) techniques, as well as its associated cultural and biological control methods [16].

All EU member states, as well as countries that are in the process of accession to the EU, are required to adopt the legislation of pesticide use. The integration of the EU environmental objectives into the national agricultural policies is of particular importance for South Eastern Europe (SEE) countries characterized by rich biodiversity. For example, Serbia although occupies only $1.9 \%$ of the European continent is habitat for: $39 \%$ of the vascular flora, $51 \%$ of the fish fauna, $49 \%$ of reptile and amphibian fauna, 74\% of the bird fauna, and $67 \%$ of the mammal fauna of this continent [17].

Considering the last available EUROSTAT [18] and FAOSTAT [19] data it is obvious that the countries from SEE do not belong to the countries which have the highest consumption of pesticides in Europe. Namely, in 2016 average use of pesticides per hectare of cropland was $1.86 \mathrm{~kg}$ in Croatia, $2.02 \mathrm{~kg}$ in Albania, $1.03 \mathrm{~kg}$ in Bulgaria, $0.72 \mathrm{~kg}$ in Romania - almost twice less than in Germany which recorded consumption of $3.92 \mathrm{~kg}$ in the same year. The SEE countries traditionally use less pesticides than the most developed nations in Europe, so they will not have problems implementing the new EU policy's objectives.

There is a growing number of research on the effect of different factors on pesticide use and general conclusion [20] that economic considerations may help understand the environmental indicators, which have an inclusive role in creating agri-environmental policies. However, there is a lack of examination of factors contributing to the use of pesticides in the SEE, so the main objective of this article is to find the main determinants that influence pesticide use in the SEE countries using the methodological framework of panel data. In accordance with the stated objective of the research, the paper starts with the following hypothesis: There is a statistically significant influence of indicators of socio-economics development and model of the structure of agricultural holdings on pesticide use in the SEE countries.

The use of pesticides is influenced by multiple factors, including gross domestic products (GDP), foreign direct investments (FDI), international trade, level of democracy, farm size, and weather conditions [21]. After the collapse of the centrally-planned system, SEE countries opened their economies, undergo a set of structural reforms, adjusted the macroeconomic policies, but all initially recorded output losses - the real GDP growth was virtually negative. [22]. The recovery differed across the countries and lies between the successful transitions in Slovenia and the abortive transition in Serbia [23]. However, Serbia recovered from the Kosovo war and showed higher growth rates of GDP in recent years. Croatia is by far the richest country in our sample, followed by Romania. Albania and North Macedonia are the poorest two countries, which have just about 5,000 dollars GDP per capita. GDP per capita should be in inverted relation with environmental pollution. Namely, according to the Environmental Kuznets Curve (EKC), there is an inverted U-shaped curve between environmental pollution, including the use of pesticides, and per capita GDP [24-26]. EKC hypothesis implies that natural resources consumption and pollution will increase with the increase in income before reaching a certain income threshold. After reaching the income threshold, resource consumption will decrease, and environmental quality will improve with the increase of income [27]. Namely, according to a typical EKC-type relationship, 
at the first stage of income growth, there is a positive correlation with greater pesticide use. After a turning point, that relationship should be negative. Because of that, it is a rule that richer countries have established and stricter environmental rules than poorer countries [28].

Some previous researches showed a negative relationship between farm size and pesticide use. Using the simultaneous model, author Burows [29] suggests significant negative relations between the scale of operation and pesticide expenditure. Authors Ghimire and Woodward in their work [30] indicated a negative relationship between these two variables until farm size reaches 52 ha per person. Given that land fragmentation and small farm size are pronounced in the SEE [31-33] it can be expected that in these countries there is also negative relations between farm size and pesticide use.

During the 2000s the SEE countries made significant progress in trade liberalization and a regional integration process through bilateral and regional free trade agreements such as Central European Free Trade Agreement (CEFTA) and Stabilization and Association Agreement with EU. Authors Fetahi-Vehapi et al. in their research [34] found no differences on trade openness among the SEE countries, despite varying degrees of EU integration and development. In addition to this, the research indicates the positive effects of trade openness on economic growth. Recent research on influence of free trade agreements in SEE countries on trade of agri-food products showed the positive impact of these agreements on the foreign trade flows of the agri-food production, but that production and foreign trade performances are noticeably worse in the SEE than in the EU countries [35]. As influence of free trade agreements on pesticide use is concerned, authors Jorgenson and Kuykendall indicated positive relationship between trade openness and pesticide use [36]. In the countries were multinationals have its headquarters, it can be expected that pesticide consumption will increase.

From the mid-1990s onwards, the FDI has gained importance in the SEE countries [37]. However, there was a lack of interest of foreign investors during 1990s, especially in countries of Western Balkans region, so there was an upsurge in FDI in 2000s, primarily prompted by privatizations and improved prospects of the economy [38]. Although FDI has been a lesspronounced agent for structural changes in SEE [39], the benefits from the inflow occurred, including transfer of technology and enhancement of competition on the local market. Also, there were negative consequences - an increased use of pesticides [40] and increased multinationals' control of agri-food production [41].

Democracy in the SEE is still young, so each country is experiencing a different kind of crisis. For example, although the EU members, Romania and Bulgaria, made a little change in terms of effective democracy [42], while Croatia is facing the obstacles to the efficient implementation of direct democracy [43].
The majority of environmental variables - deforestation, carbon dioxide emission, and soil erosion - were negatively correlated with democracy [44]. Author Jorgenson also suggests that the opinion that democracy cannot be viewed unilaterally in its relationship to the environment [45]. In fact, democracy should promote lesser use of pesticides.

Studies agree that drought indices and heatwave intensity, length and frequency have increased in SEE [46-48]. For example, an extremely warm summer - the warmest one on record, and the third driest in history, was recorded in Serbia in 2012 [49]. In terms of climate change, increased pesticide use due to increased volatilization and accelerated degradation is expected [50]. Because of that, the influence of temperature and precipitation on pesticide use should be positive.

This paper has four sections. The introduction to the paper's main idea is developed together with a review f literature as the theoretical basis for this research. The methodology used in this paper is described in the next section, where the model construction is also shown. In the third section results of research are presented, which are then more explained in the discussion section. Implications of the main results, as well as consideration of future expectations, are described in conclusion.

\section{Material and Methods}

Analysing the level of pesticide use is not a simple task, especially in SEE countries, where there is no previous research that estimated factors that contribute to pesticide use. Namely, this paper is primarily focused on those countries that experienced in their history many turbulences, among others, transitions from a centrally-planed to a market-oriented economy. This paper analyses the six SEE countries (Romania, Bulgaria, Croatia, Serbia, North Macedonia, and Albania) over a 22-year period (1995-2016). An analysis of the impact of different factors on pesticides such as GDP per capita, farm size, trade openness, democracy index, FDI, temperature, and precipitation was conducted using a constructed model in Fig. 1.

A model was constructed based on the previous analysis of this topics in relevant literature:

$$
\begin{gathered}
\ln \mathrm{X}_{\mathrm{it}}=\ln \alpha+\beta_{1} \ln \left(\mathrm{GDPpc}_{\mathrm{it}}\right)+\beta_{2} \ln \left(\mathrm{FS}_{\mathrm{it}}\right) \\
+\beta_{3} \ln \left(\mathrm{TO}_{\mathrm{it}}\right)+\beta_{4} \ln \left(\mathrm{DEM}_{\mathrm{it}}\right)+\beta_{5} \ln \left(\mathrm{FDI}_{\mathrm{it}}\right) \\
+\beta_{6} \ln \left(\mathrm{TEM}_{\mathrm{it}}\right)+\beta_{7} \ln \left(\mathrm{PRE}_{\mathrm{it}}\right)+\beta_{8} \mathrm{EU}_{\mathrm{it}}+\mu_{\mathrm{i}} \\
+\lambda_{\mathrm{t}}+\mathrm{u}_{\mathrm{it}}
\end{gathered}
$$

where:

- $\mathrm{X}_{\mathrm{it}}-$ represents the pesticide use in the country $\mathrm{i}$ in period t;

- $\mathrm{GDPpc}_{\mathrm{it}}$ - represents GDP per capita in the country $i$ in period $t$; 


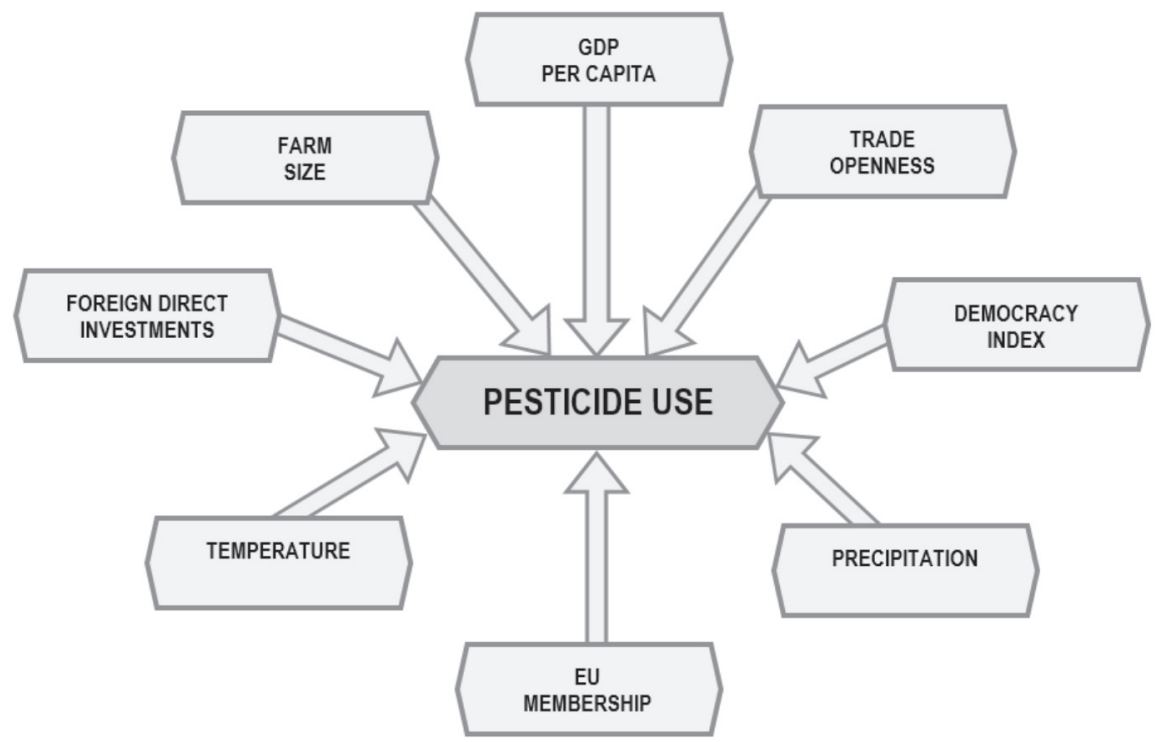

Fig. 1. Model for identifying the pesticide use in the SEE countries. Source: The authors' illustration.

- $\mathrm{FS}_{\mathrm{it}}-$ represents farm size in the country $\mathrm{i}$ in period t;

- $\mathrm{TO}_{\mathrm{it}}-$ represents trade openness in the country $\mathrm{i}$ in period $\mathrm{t}$;

- $\mathrm{DEM}_{\mathrm{it}}$ - represents democracy index in the country $i$ in period $t$;

- $\mathrm{FDI}_{\mathrm{it}}$ - represents FDI as a proportion of GDP in the country $\mathrm{i}$ in period $\mathrm{t}$;

- $\mathrm{TEM}_{\mathrm{it}}-$ represents average yearly temperature in the country $i$ in period $t$;

- $\mathrm{PRE}_{\mathrm{it}}$ - represents average precipitation in the country $\mathrm{i}$ in period $\mathrm{t}$;
- $\mathrm{EU}_{\mathrm{it}}$ - represents a dummy variable which covers the effects of membership in the EU on pesticide use. The variable has the value 1 for EU member states, and the value 0 for other countries;

- $\mu_{\mathrm{i}}$ and $\lambda_{\mathrm{t}}-$ represent cross-section and period specific effect (fixed or random), respectively;

- $u_{i t}$ - random error of the model.

This research includes data obtained from several sources (Table 1): the Food and Agriculture Organization Statistical data base [51], World Bank data base [52], Freedom House [53], Ministry of Agriculture, Forestry and Water Management of Republic of Serbia

Table 1. Description of variables.

\begin{tabular}{|c|c|c|c|}
\hline Variable & Variable Description & Data Source & $\begin{array}{c}\text { Expected } \\
\text { relationship }\end{array}$ \\
\hline Pesticide use (X) & $\begin{array}{c}\text { Use of pesticide by country in kg per hectare } \\
\text { of cropland }\end{array}$ & $\begin{array}{c}\text { FAOSTAT, } \\
\text { MAFW }\end{array}$ & WB \\
\hline $\begin{array}{c}\text { Gross Domestic Product per } \\
\text { capita (GDPp) }\end{array}$ & $\begin{array}{c}\text { GDP per capita expressed in constant 2010 } \\
\text { U.S. dollars }\end{array}$ & $\begin{array}{c}\text { Positive/ } \\
\text { Negative }\end{array}$ \\
\hline Farm size (FS) & $\begin{array}{c}\text { Farm size per capita - total arable and } \\
\text { permanent cropland per population engaged } \\
\text { in agriculture }\end{array}$ & FAOSTAT & Negative \\
\hline Trade openness (TO) & $\begin{array}{c}\text { Trade openness include sum of export and } \\
\text { import as percent of GDP }\end{array}$ & WB & Positive \\
\hline Democracy index (DEM) & Democracy index by country & Freedom House & Negative \\
\hline Foreign Direct Investments (FDI) & FDI as a proportion of GDP & WB & Negative/ Positive \\
\hline Temperature (TEM) & $\begin{array}{c}\text { Average yearly temperature in degree } \\
\text { centigrade }\end{array}$ & Positive \\
\hline Precipitation (PRE) & Mean precipitation in mm per year & WB & Positive \\
\hline Membership in the EU (EU) & $\begin{array}{c}\text { Dummy variable - 1 for EU member states, } \\
\text { and the value 0 for other countries }\end{array}$ & Positive \\
\hline
\end{tabular}

Source: The authors' composition. 
(MAFW) [54] and European Commission [55]. For data of pesticide use, an exception applies in the case of Serbia in which it is not possible to obtain all necessary data from FAOSTAT. Thus, data on pesticide usage for Serbia and Montenegro (till 2006 Montenegro and Serbia were nominally part of the same country) from FAOSTAT until 2000 was used, while after 2000 data on pesticide import from the MAFW was used.

In the case of no available data of pesticide usage, pesticide import data can be useful [56], especially in countries that are largely dependent on pesticide imports [57].

The expected impact of independent variables on the dependent variable is shown in Table 1. Namely, it is expected to find an inverted EKC U-curve specification between GDP per capita and pesticide use. As a general rule, at the first stage of income growth, there is a positive correlation with pesticide use. After turning point, that relationship should be negative $[58,59]$. Also, it is expected that with decreasing dependence on the
FDI, environmental awareness is expected to increase, so the relationship between the use of pesticides and FDI should take the form of a U-curve. It is expected that farm size and democracy index negatively influence on pesticide use in constructed model, while the influence of trade openness, temperature, precipitation, and EU membership is expected to be positive.

\section{Results and Discussion}

Out of the six observed SEE countries in our sample, there were two countries (Serbia and Albania) that showed an upward trend of use of pesticides (I-style), while three countries (Romania, Croatia and North Macedonia) showed a downward trend in pesticide use. One country, Bulgaria, exhibiting $\mathrm{N}$-style in pesticide use, where usage of pesticides firstly decreased until 2014, and after that, their usage increased (Fig. 2).

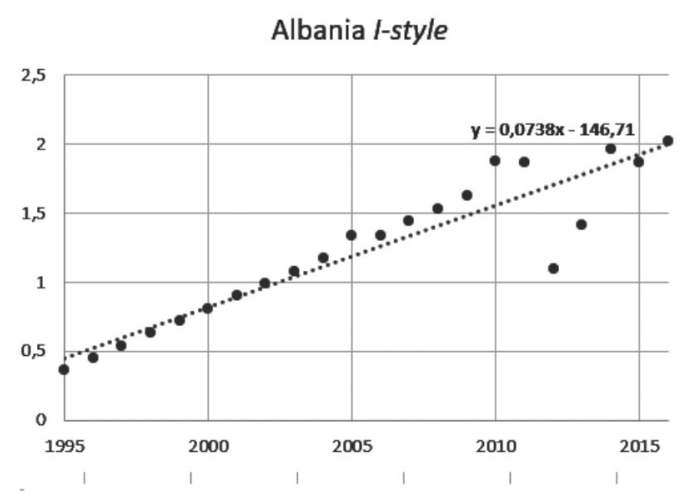

Bulgaria - $\mathrm{N}$-style

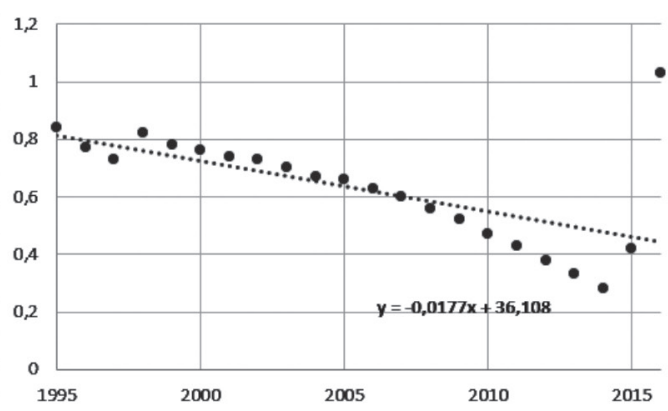

Croatia - D-style

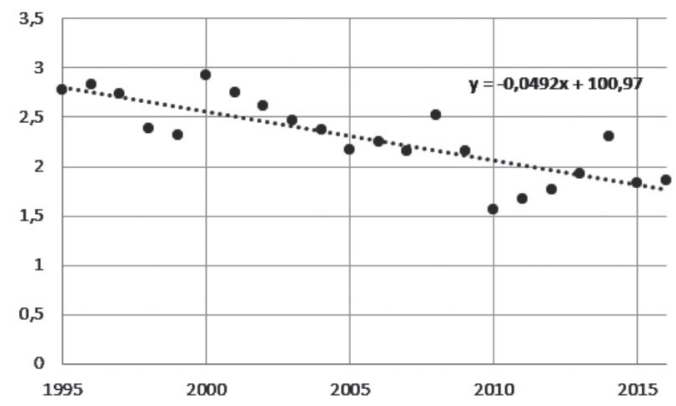

Serbia - I-style

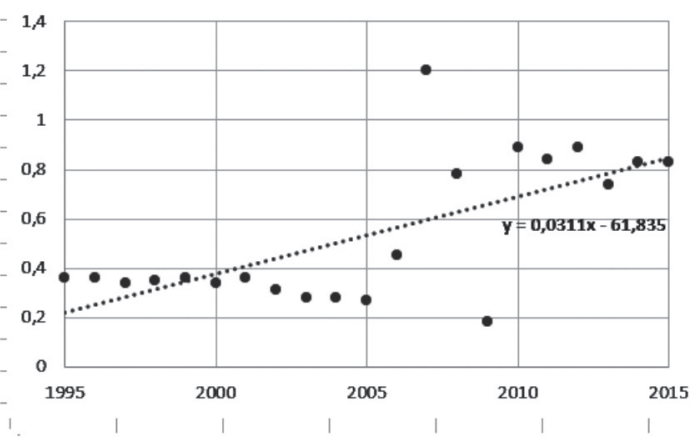

Romania - D-style

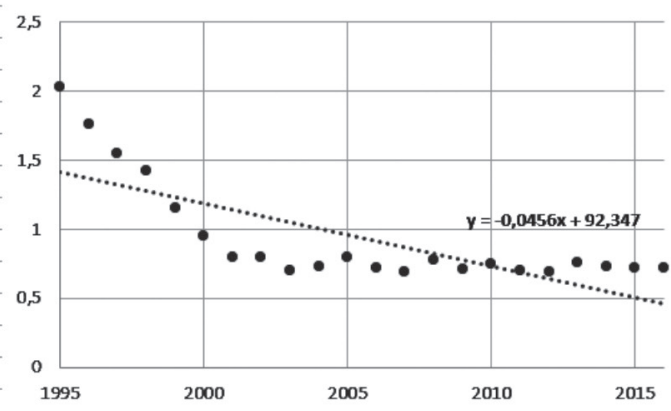

North Macedonia - D-style

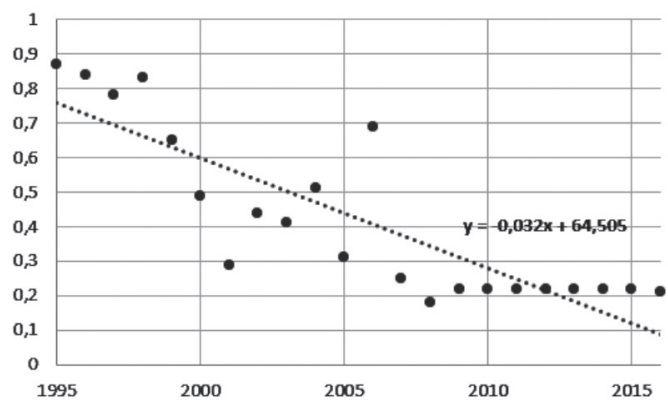

Fig. 2. Illustrative examples for three styles of pesticide use in the SEE. Source: The authors' illustration. 
Table 2. Descriptive statistics.

\begin{tabular}{|c|c|c|c|c|c|}
\hline Variable & Mean & Median & S.D. & Min & Max \\
\hline Pesticide use X & 1.01 & 0.765 & 0.722 & 0.180 & 2.92 \\
\hline GDPpc & 6.201 & 4.910 & 3.424 & 1.676 & 15.207 \\
\hline FS & 5.04 & 3.86 & 4.11 & 1.10 & 18.5 \\
\hline TO & 78.4 & 77.5 & 21.8 & 23.2 & 131.9 \\
\hline DEM & 5.15 & 5.50 & 1.24 & 1.00 & 6.50 \\
\hline FDI & 4.95 & 3.68 & 4.28 & 0.200 & 31.24 \\
\hline TEM & 11.1 & 11.1 & 0.975 & 8.49 & 13.32 \\
\hline PRE & 810.4 & 753.0 & 217.7 & 404.5 & 1442.0 \\
\hline
\end{tabular}

Source: The authors' calculations.

Descriptive statistics for all variables are shown in Table 2. The results from the table show that there are significant differences among pesticide use in SEE countries. Per capita pesticide use ranges from $0.18 \mathrm{~kg}$ per hectare to $2.92 \mathrm{~kg}$, with the mean value of $1 \mathrm{~kg}$ in the selected countries for the analysed period. Croatia was the country with the highest average pesticide use during the time of 1995-2016 - $2.29 \mathrm{~kg}$ per ha, while

Table 3. Model estimation.

\begin{tabular}{|c|c|c|c|c|}
\hline \multicolumn{5}{|c|}{ Method: Panel Least Squares } \\
\hline \multicolumn{3}{|c|}{ Sample: } & \multicolumn{2}{|c|}{19952016} \\
\hline \multicolumn{3}{|c|}{ Periods included: } & \multicolumn{2}{|c|}{22} \\
\hline \multicolumn{3}{|c|}{ Cross-sections included: } & \multicolumn{2}{|c|}{6} \\
\hline \multicolumn{3}{|c|}{ Total panel (balanced) observations: } & \multicolumn{2}{|c|}{132} \\
\hline Variable & Coefficient & Std. Error & t-Statistic & Prob. \\
\hline $\mathrm{C}$ & -11.73854 & 1.677662 & -6.996964 & 0.0000 \\
\hline GDPPC & 0.842474 & 0.125939 & 6.689519 & 0.0000 \\
\hline FS & -0.295619 & 0.089589 & -3.299723 & 0.0013 \\
\hline TO & -0.442373 & 0.206727 & -2.139890 & 0.0343 \\
\hline DEM & 0.314032 & 0.173434 & 1.810672 & 0.0726 \\
\hline FDI & -0.007841 & 0.059401 & -0.132008 & 0.8952 \\
\hline TEM & 0.777668 & 0.628616 & 1.237111 & 0.2184 \\
\hline PRE & 0.638852 & 0.236928 & 2.696392 & 0.0080 \\
\hline EU & -0.285004 & 0.143629 & -1.984307 & 0.0494 \\
\hline Root MSE & 0.503027 & \multicolumn{2}{|c|}{ R-squared } & 0.526238 \\
\hline Mean dependent var & -0.245037 & \multicolumn{2}{|c|}{ Adjusted R-squared } & 0.495424 \\
\hline S.D. dependent var & 0.733605 & \multicolumn{2}{|c|}{ S.E. of regression } & 0.521105 \\
\hline Akaike info criterion & 1.600016 & \multicolumn{2}{|c|}{ Sum squared resid } & 33.40072 \\
\hline Schwarz criterion & 1.796571 & \multicolumn{2}{|c|}{ Log likelihood } & -96.60108 \\
\hline Hannan-Quinn criter. & 1.679887 & \multicolumn{2}{|c|}{ F-statistic } & 17.07800 \\
\hline Durbin-Watson stat & 0.592799 & \multicolumn{2}{|c|}{ Prob (F-statistic) } & 0.000000 \\
\hline $\mathrm{BP} / \mathrm{CV}$ & 0.058100 & \multicolumn{2}{|c|}{ Mean VIF } & 1.80 \\
\hline
\end{tabular}

Source: The authors' calculations. 
North Macedonia was the country with the lowest usage of pesticides in the same period $-0.42 \mathrm{~kg}$ per ha.

In the estimated model (Table 3), all data for all years were available for all SEE countries, so the panel is balanced. The Panel Least Squares model was used to analyse the impact of indicators on the pesticide use in the SEE countries. According to the estimated model, GDP per capita and precipitation had a positive impact on pesticide use in the SEE countries, while farm size, trade openness, and EU membership negatively affected the pesticide use. The model shows that these variables had a significant impact on the dependent variable, while variables Foreign Direct Investments, democracy index and temperature did not have a statistically significant influence on the pesticide use in analysed countries.

Validation of the model is presented by $\mathrm{F}$ results and by the statistically significant impact of most of the variables on pesticide use $(p<0.05)$. The model explains $52.62 \%$ of explanatory variables variations, and model reliability was confirmed through testing on multicollinearity, heteroscedasticity, and autocorrelation. Namely, according to the value of a variance inflation factor test (mean VIF $=1.80$ ), in the model, there is no problem of multicollinearity because the value of VIF is less than the reference value of 10 . Based on the Durbin-Watson stat, it can be concluded that there is no problem of the autocorrelation of residuals (Durbin-Watson stat $=0.592799>\mathrm{dL}=0.587$ ). According to Breusch-Pagan, Cook-Weisberg (BP/ $\mathrm{CW})$ test for heteroscedasticity, there is no problem of heteroscedasticity because values of 0.0581 are more than 0.05 , so null hypothesis that supposes homoscedasticity cannot be rejected. We involved all basic prerequisites in econometric modelling and based on Table 3 model is well designed for optimal econometric estimation.

The influence of GDP per capita on pesticide use is significant and positive, which is in line with our expectations. It could also be negative, but on this stage of economic development in SEE countries, there is an increase in GDP per capita for $1 \%$ influence on the increase of pesticide use for $0.84 \%$. A negative sign on the coefficient of farm structure is also expected, so pesticide usage is more characteristic for small farms. There are also some other contrary researches, which indicated that higher incidence of pesticides use largesized farms [60]. Interestingly, trade openness had the opposite effect of what had been predicted. According to estimated results, trade openness had a negative influence on pesticide use in SEE countries. This can be explained by the example of small European countries with lower levels of partial productivity of agriculture and specific fragmented farm structures. Although democracy in SEE countries is still young, the estimated model results did not show the impact of democracy index on pesticide use. According to the theoretical background, democracy should influence on lesser usage of pesticide.
Interestingly, dummy variable, membership in EU, showed the negative effect that membership in the EU enhanced these countries' pesticide use. This can be explained that the analysis covers recent EU member states, which are at the same time, economically least developed countries of the Union. Deepening the analysis with relatively more developed EU countries would certainly show different results to the estimated model.

Although it is noted that SEE countries are not among the largest users of pesticides due to the extensiveness of their agriculture, it is clear that for all SEE countries, changes in EU regulation and the physiognomy of Common Agricultural Policy (CAP) of EU itself will have a dominant impact on pesticide use. As environmental protection within the CAP framework has played an increasingly important role in the last two decades [61], the direction of development in the new budget period will have a key impact on all SEE countries, because three of the analysed countries are already part of the EU and another analysed countries are candidates for EU membership. The key objectives of the CAP for the period 2021-2027 are focused on enhanced environmental and climate performance, as well as on economic viability, resilience and farm income and on the enhanced socio-economic fabric of rural areas. So, for the Bulgaria, Romania and Croatia, which are the part of EU, the eco-schemes will provide public goods by agricultural practices which are beneficial to the environment and climate, and it will be up to member states to define these practices provided they contribute to the three specific CAP objectives linked to bolstering environmental and climate action [62]. However, in the other analysed SEE countries, which are not part of the EU (Serbia, Albania, and North Macedonia), the support for improving the environment is insignificant [63], so in pre-accession period special attention should be given in harmonization of these measures.

The creators of agricultural policy should pay particular attention to the increase of sustainable production methods, like organic farming. The market of organic food has been increasing [64], so the support of organic farming in SEE countries would give results in protection of the environment from pesticide. Namely, organic farming prohibits the use of synthetic chemical pesticides which led soil, water resources and air have been protected from contamination, so organic farming led to the sustainable use of resources [65]. In SEE countries that are member states of the EU, support to organic farming is regulated with CAP's framework. In North Macedonia and Serbia, support for organic farming is not defined in absolute amounts per hectare or per livestock unit as compensation for higher costs, but as a supplement to payments for conventional production, while in Albania there have not established special support for organic farming yet [66]. This type of farming will certainly have positive impact on the environment, and because of that, it is important for all 
SEE countries that attention and support focus in that direction.

\section{Conclusions}

This paper investigated the relationship between pesticide use and different socio-economic and environmental determinants. The main hypothesis of this research is confirmed as a key finding in our estimated model was that the influence on GDP per capita on pesticide use is significant and still positive, which is characteristic for countries on relatively lower economic development stages. Also, as expected, farm structure had a negative impact on pesticide use, while the influence of trade openness also had a negative impact on pesticide use, which is the opposite sign than we predicted.

For all SEE countries, changes and mechanisms of CAP will significantly influence on pesticide use. Namely, three analysed countries are young EU member states, while three others are in the process of harmonising regulation before joining the EU. In this process, funds for pre-accession assistance for agriculture and rural development will have an important role. One of the measures which candidate countries should include in measures of these funds needs to be connected to agri-environmental measures. Some countries already have some of these measures, like support for organic farming, which strictly prohibits using syntactic pesticides.

Although this research represents a rather descriptive study of very complex phenomena, to the extent of our knowledge, it is the first study to address the influence of multiple factors on the use of pesticides in SEE countries. Monitoring of the situation is extremely important since it represents the stepping stone for evidence-based action, necessary to tackle the burden in terms of environmental cost. At the same time, that is the main contribution of this research. Namely, these research results are essential for policymakers, especially in the process of EU integration and harmonisation of legislation of pesticide use in SEE countries and the EU. Since there are a limited number of papers analysing determinants of pesticide use of the SEE countries, the research will contribute to filling this gap in the literature. In that context, in the focus of our future research, we will analyse the pesticide use of all countries of the EU to better understand their usage in SEE and how other countries with similar economic history adopted pesticide mechanisms changes.

\section{Acknowledgements}

This paper represents a part of the research on the project of the Ministry of Education, Science and Technological Development, Republic of Serbia, No.
46006, entitled: Sustainable Agriculture and Rural Development in terms of the Republic of Serbia strategic goals implementation within Danube region.

\section{Conflict of Interest}

The authors declare no conflict of interest.

\section{References}

1. HARRIS JM., ROACH B. Environmental and Natural Resource Economics: A Contemporary Approach. ME Sharpe: New York, London, 2013.

2. PIMENTEL D., BURGESS M. Environmental and Economic Costs of the Application of Pesticides Primarily in the United States. In Primentel D., Peshin R., Eds., Integrated Pest Management. Springer: Dordrecht, 47, 2014.

3. POPP J., PETO K., NAGY J. Pesticide productivity and food security. A review. Agronomy for Sustainable Development, 33, 243, 2013.

4. MAKSYMIV I. Pesticides: benefits and hazards. Journal of Vasyl Stefanyk Precarphathian National University, 2 (1), 70, 2015.

5. COOPER J., DOBSON H. The benefits of pesticides to mankind and the environment. Crop Protection, 26 (9), 1337, 2007.

6. MAHMOOD I., IMADI S. R., SHAZADI K., GUL A., HAKEEM K. R. Effects of pesticides on environment. In Plant, soil and microbes. Springer: Cham, 253, 2016.

7. KIM K. H., KABIR E., JAHAN S. A. Exposure to pesticides and the associated human health effects. Science of the Total Environment, 575, 525, 2017.

8. CARVALHO F.P. Pesticides, environment, and food safety. Food and Energy Security, 6 (2), 48, 2017.

9. LEACH A.W., MUMFORD JD. Pesticide environmental accounting: A method for assessing the external costs of individual pesticide applications. Environmental Pollution, 151 (1), 139, 2008.

10. ANTONINI C., ARGILES-BOSCH JM. Productivity and environmental costs from intensification of farming. A panel data analysis across EU regions. Journal of Cleaner Production, 140, 796, 2017.

11. EUROPEAN UNION - EU, Decision No 1386/2013/ EU of the European Parliament and of the Council of 20 November 2013 on a General Union Environment Action Programme to 2020 'Living well, within the limits of our planet', Annex A, paragraph 54e (OJ L 354: 171-200), 2013.

12. European Environment Agency - EEA, Pesticide sales. Available online: https://www.eea.europa.eu/airs/2018/ environment-and-health/pesticides-sales (accessed on 10 March 2020).

13. European Environment Agency - EEA, Pesticide sales. Available online: https://www.eea.europa.eu/airs/2018/ environment-and-health/pesticides-sales (accessed on 10 March 2020).

14. SLUIS VAN DER T., PEDROLI B., KRISTENSEN S.B., COSOR G.L., PAVLIS E. Changing land use intensity in Europe - Recent processes in selected case studies. Land Use Policy 57, 777, 2016. 
15. LABUSSIÈRE E., BARZMAN M. S., RICCI P. European crop protection in 2030. A foresight study, 2010.

16. HANDFORD C.E., ELLIOTT C.T., CAMPBELL K. A review of the global pesticide legislation and the scale of challenge in reaching the global harmonization of food safety standards. Integrated environmental assessment and management, 11 (4), 525, 2015.

17. AMIDŽIĆ L., BARTULA M., CVETKOVIĆ D. The state of biodiversity in Serbia. Natural Areas Journal, 34 (2), 222, 2014.

18. European Statistics - EUROSTAT, Official Database, Available online: https://ec.europa.eu/eurostat (accessed on 10 February 2020).

19. Food and Agricultural Organization - FAO, FAOstat Database. Available online: http://www.fao.org/faostat/ en/\#data (accessed on 20 February 2020).

20. GÜRLÜK S., UZE G. An evaluation of agri-environmental indicators through a multi-criteria decision-making tool in Germany, France, the Netherlands, and Turkey. Polish Journal of Environmental Studies, 25 (4), 1523, 2016.

21. GHIMIRE N., WOODWARD R.T. Under-and overuse of pesticides: An international analysis. Ecological Economics, 89, 73, 2013.

22. TRPKOVA M., TASHEVSKA B. Determinants of economic growth in South-East Europe: A panel data approach. Perspectives of Innovations, Economics and Business, 7 (1), 12, 2011.

23. STANOJEVIC M. Workers' power in transition economies: the cases of Serbia and Slovenia. European Journal of Industrial Relations, 9 (3), 283, 2003.

24. LI F., DONG S., LI F., YANG L. Is there an inverted U-shaped curve? Empirical analysis of the Environmental Kuznets Curve in agrochemicals. Frontiers of Environmental Science \& Engineering, 10, 276, 2016.

25. SHI R., SHANG J. ZHANG B. Relationship between Agricultural Non-Point Source Pollution and Economic Growth Based on EKC Model. Rev. Fac. Agron., 36 (6), 2216, 2019.

26. HEDLUND J., LONGO S., YORK R. Agriculture, Pesticide Use, and Economic Development: A Global Examination (1990-2014). Rural Sociology, 85 (2), 519, 2019.

27. WANG Y., SHEN N. Agricultural environmental efficiency and agricultural environmental Kuznets curve based on technological gap: The case of China. Polish Journal of Environmental Studies, 25 (3), 1293, 2016.

28. ZEKIĆ S., MATKOVSKI B., KLEUT Ž. Analiza agroekoloških indikatora u Srbiji i zemljama Evropske unije. Anali Ekonomskog fakulteta u Subotici, 54 (39), 45, 2018.

29. BURROWS T.M. Pesticide demand and integrated pest management: a limited dependent variable analysis. American Journal of Agricultural Economics, 65 (4), 806, 1983.

30. GHIMIRE N., WOODWARD R.T. Under-and overuse of pesticides: An international analysis. Ecological Economics, 89, 73, 2013.

31. PETRESCU-MAG R.M., PETRESCU D.C., PETRESCUMAG I.V. Whereto land fragmentation - land grabbing in Romania? The place of negotiation in reaching win-win community-based solutions. Land Use Policy, 64 (2017), 174, 2017.

32. DI FALCO S., PENOV I., ALEKSIEV A., VAN RENSBURG T. M. Agrobiodiversity, farm profits and land fragmentation: Evidence from Bulgaria. Land Use Policy, 27 (3), 763, 2010.
33. LOVRE K. Technical change in agricultural development of the Western Balkan countries. In $152^{\text {nd }}$ EAAE Seminar - Emerging technologies and the development of agriculture, Tomić D., Lovre K., Subić J., Ševarlić M., Eds., Serbian Association of Agricultural Economists, Faculty of Economics in Subotica, Institute of Agricultural Economics: Novi Sad, Serbia, 1, 2016.

34. FETAHI-VEHAPI M., SADIKU L., PETKOVSKI M. Empirical analysis of the effects of trade openness on economic growth: an evidence for South East European countries. Procedia Economics and Finance, 19 (2015), 17, 2015.

35. MATKOVSKI B., ZEKIĆ S, SAVIĆ M., RADOVANOV B. Trade of agri-food products in the EU enlargement process: evidence from the Southeastern Europe. Agricultural Economics - Czech, 64 (8), 357, 2018.

36. JORGENSON A.K., KUYKENDALL K.A. Globalization, foreign investment dependence and agriculture production: Pesticide and fertilizer use in less-developed countries, 1990-2000. Social Forces, 87 (1), 529, 2008

37. United Nations Conference on Trade and Development - UNCTAD, World Investment Directory, Volume VIII: Central and Eastern Europe, United Nations: New York and Geneva, 2003

38. ESTRIN S., UVALIC M. Foreign Direct Investment in the Western Balkans: What Role has it Played during Transition? Comparative Economic Studies, 58, 455, 2016.

39. KALOTAY K. Patterns of inward FDI in economies in transition. Eastern Journal of European Studies, 1 (2), 55, 2010.

40. JORGENSON A.K. Foreign direct investment and pesticide use intensity in less-developed countries: A quantitative investigation. Society and natural resources, 20 (1), 73, 2007.

41. JORGENSON A.K., KUYKENDALL K.A. Globalization, foreign investment dependence and agriculture production: Pesticide and fertilizer use in less-developed countries, 1990-2000. Social Forces, 87 (1), 529, 2008.

42. RACOVIȚĂ M. Europeanization and effective democracy in Romania and Bulgaria. Romanian Journal of Political Sciences, 11 (1), 28, 2011.

43. BUTKOVIĆ H. The Rise of Direct Democracy in Croatia: Balancing or Challenging Parliamentary Representation? Croatian International Relations Review, 23 (77), 39, 2017.

44. MIDLARSKY M.I. Democracy and the environment: an empirical assessment. Journal of Peace Research, 35 (3), 341, 1998.

45. JORGENSON A.K. Foreign direct investment and pesticide use intensity in less-developed countries: A quantitative investigation. Society and natural resources, 20 (1), 73, 2007.

46. ALEXANDER L.V. Global observed long-term changes in temperature and precipitation extremes: A review of progress and limitations in IPCC assessments and beyond. Weather and Climate Extremes, 11, 4, 2016.

47. SHEFFIELD J., WOOD E. Projected changes in drought occurrence under future global warming from multimodel, multi-scenario, IPCC AR4 simulations. Clim Dyn, 31 (1), 79, 2008

48. KUGLITSCH F, TORETI A, XOPLAKI E, DELLAMARTA P, ZEREFOS C, TÜRKESं M, LUTERBACHER $J$. Heat wave changes in the eastern Mediterranean since 1960. Geophysical Research Letters, 37 (4), 1, 2010.

49. Hydro meteorological Service of Serbia, Official Website. Available online: http://www.hidmet.gov.rs/index_eng.php (accessed on 25 February 2020). 
50. DELCOUR I., SPANOGHE P., UYTTENDAELE M. Literature review: Impact of climate change on pesticide use. Food Research International, 68 (2015), 7, 2015.

51. Food and Agricultural Organization - FAO, FAOstat Database. Available online: http://www.fao.org/faostat/ en/\#data (accessed on 20 February 2020).

52. World Bank - WB, World Development Indicators. Available online: http://databank.worldbank.org/data/ reports.aspx?sour ce $1 / 4$ world-development-indicators (accessed on 2 February 2020).

53. Freedom House, Official Website. Available online: https:// freedomhouse.org/ (accessed on 25 February 2020).

54. Ministry of Agriculture, Forestry and Water Management of Republic of Serbia - MAFW, Official Website. Available online: http://www.minpolj.gov.rs/ (accessed on 25 February 2020).

55. European Commission - EC, Official Website. Available online: https://ec.europa.eu/ (accessed on 25 February 2020).

56. LIU Y., PAN X., LI J. Current agricultural practices threaten future global food production. Journal of Agricultural and Environmental Ethics, 28 (2), 203, 2015.

57. MILANOVIĆ M.R., STEVANOVIĆ S., DIMITRIJEVIĆ B. Agrarian potentials in the reindustrialization of Serbia import of inputs and the opportunity costs of development. Economics of Agriculture, 63 (1), 143, 2016.

58. SHI R., SHANG J. ZHANG B. Relationship between Agricultural Non-Point Source Pollution and Economic Growth Based on EKC Model. Rev. Fac. Agron., 36 (6), 2216, 2019.

59. HEDLUND J., LONGO S., YORK R. Agriculture, Pesticide Use, and Economic Development: A Global Examination (1990-2014). Rural Sociology, 2019.
60. DASGupta S., MAMINGI N., MEISNER C. Pesticide use in Brazil in the era of agroindustrialization and globalization. Environment and Development Economics, $6(4), 459,2001$.

61. ZEKIĆ S., KLEUT Ž., MATKOVSKI B., ĐOKIĆ D. Determining agricultural impact on environment: Evidence for EU-28 and Serbia. Outlook on Agriculture, 47 (2), 116, 2018.

62. MATTHEWS A. The EU's Common Agricultural Policy Post 2020: Directions of Change and Potential Trade and Market Effects. International Centre for Trade and Sustainable Development (ICTSD): Geneva, 2018.

63. VOLK T., REDNAK M., ERJAVEC E. Agricultural policy developments in Western Balkan countries regional synthesis, In Monitoring of agricultural policy developments in the Western Balkan countries. Volk, T., E. Erjavec, P. Ciaian, S. Gomez y Paloma, Eds., European Commission, Joint Research Centre, 2017.

64. KONCAR J., GRUBOR A., MARIC R. Improving the placement of food products of organic origin on the AP Vojvodina market. Strategic Management, 24 (3), 24, 2019.

65. CUKUR T., KIZILASLAN N., KIZILASLAN H. Analysis of the factors affecting the adoption of organic farming in Turkey: The case of Samsun Province. Applied Ecology and Environmental research, 17 (6), 14001, 2019.

66. MATTHEWS A. The EU's Common Agricultural Policy Post 2020: Directions of Change and Potential Trade and Market Effects. International Centre for Trade and Sustainable Development (ICTSD): Geneva, 2018. 